\title{
AN ANALYSIS OF FIGURATIVE LANGAUGE IN THE NOVEL
}

THERE YOU'LL FIND BY JENNY B. JONES

\author{
Saum Maria Magdalena
}

\begin{abstract}
The objectives of this research are (1) to find out what kinds of figurative language used in the novel, (2) to find out what figurative language the novel used widely and (3) to find out what figurative language used least. The data the researcher analyzed is all sentences which consist of figurative language mentioned in the source of theories in the chapter two of this term paper. The used data source is the novel entitled There you'll Find Me by Jenny B. Jones. The researcher analyzed the novel by underlining every single sentence found containing figurative language. Then list them in a table and percentage their each types. The researcher found there are 11 figurative languages or, in other words, the novel used all kinds of figure of speech mentioned according to the expert's theories in total use of 479 figurative languages. The percentage table shows the result that the use of metaphor is 35 or $7.3 \%$, simile 70 or $14.6 \%$, personification 81 or $16.9 \%$, apostrophe 15 or $3.1 \%$, overstatement (hyperbole) 162 or $33.8 \%$, understatement (litotes) 23 or $4.8 \%$, metonymy 20 or $4.2 \%$, synecdoche 18 or $3.8 \%$, transferred epithet 37 or $7.7 \%$, paradox 15 or $3.1 \%$, and pun 3 or $0.6 \%$. According to the result, overstatement (hyperbole) is the most widely used figure of speech, and pun is the least one. The result of this research can give the readers about kinds of figurative languages; perhaps, they found some are new for them. Hopefully, the author of the novel keeps going creating such an interesting yet meaningful story through many other kinds of figurative language.
\end{abstract}

Keywords: An analysis of figurative language, figurative language, figure of speech.

\section{A. INTRODUCTION}

\section{Background of the Study}

Ray Harvey (2015:para 1) defines that literature is "the art-form of language, and words are its tool. As the painter uses paint, as a musician uses musical instruments, as a sculptor uses stone-and-chisel, so a writer uses words." 
Through this definition, it could be concluded that word has an important role in any kinds of written works especially in literature. Words also are a tool for writers to pour their thoughts out into writing. Since the words the writer using possess certain meaning, they should have been very careful in using the appropriate ones

Another important point of a written work is clarity. Harvey also states in his journal that "clarity is the number one priority in all issues of writing style" (Ray Harvey,2015). On the other hand, it is still possible for a writer to make mistakes by choosing words wrongly. Moreover, the needs of every literary man to be able to portray their works more vivid and more interesting cannot be ruled out. So, the researcher believes that to help every literary man well transform their opinion to the readers and to help the readers visualize what is happening in the literary work they are reading is by using figurative language.

Figurative language is very easy to find in poetry, but is used in prose and nonfiction writing, such as novel, as well. Through the beauty of the language and its out-of-usual form, figurative language can enhance every literary works and be the easiest way of getting image or a point across for every literary man. For instance, when a woman was in a party and met a man that said to her, 'Wow...You look like a billion dollars tonight' Was the man really meant he literally see billion dollars money in her? Certainly not, he wanted to say that she looked very beautiful in the party. So why doesn't he just say, 'Wow... You look very beautiful'? Because that's figurative language is for. It is for clarifying and describing in more detail. As it is known, people have many different words in different level to say a woman is beautiful. It could be gorgeous, stunning, charming, perfect, admirable, pretty, cute, and many more. With no doubt, figurative language is very useful in giving accurate descriptions. However, used it incorrectly can make the readers confused or downright silly. Thus, the researcher is anxious to analyze the use of figurative language of this novel.

In arranging this term paper, the researcher used a novel entitled There You'll Find Me by Jenny B. Jones, which is a kind of fiction novel. The researcher also found kinds of figurative language in the novel. Some of which are personification, metaphor, simile, and so on. As the reader, the researcher was very helpful fathoming the story in the novel and very impressed with the beauty of words the author used which is expressed through figurative languages. The researcher does believe that many readers out there will feel so. Therefore, the researcher wants to know more deeply the use of figurative language; which figurative language used most and least one.

\section{Objectives of the Study}

The objectives of this research are (1) to find out figurative language used in this novel; (2) to find out the most widely used figurative language in this novel; and (3) to find out the least used figurative language in this novel. 


\section{Theoretical Framework}

In this chapter, the researcher explains about the theories relating to the study which is being discussed. Those theories are very important and useful for a researcher to conduct the research. They are to support and strengthen the researcher's thoughts, also to prove that what the researcher believes is true. Not only the theories of figurative language do the researcher state but also the theory about semantic, known has a relation with the figurative language itself.

\subsection{Semantic}

Figurative language is closely related with meaning, and the study of linguistic that learns about meaning is semantics. Kate Kearns (2011:1) in her book says "Semantics deals with the literal meaning of words and the meaning of the way they are combined, which taken together from the core of meaning, or the starting point from which the whole meaning of a particular utterance is constructed." The same definition of semantics comes from James R. Hurford, Brendan Heasley, and Michael B. Smith (2007:1) in their book that more simply defines "Semantics is the study of meaning in language." Mark Liberman (2015:para 1) in his online course says that "Semantics can be defined as the study of meaning of morphemes, words, phrases, and sentences." Those three definitions of semantics that comes from different people share the same thing that semantics is the study of meaning in language.

Mark Liberman (2015:para 3) then gives a more detail explanation about semantics that when semantics is defined as the analysis of a meaning, it is just too broad. For further comprehension, consider this example. Kim, returning home after a long day, discovers that the new puppy has crapped on the rug, and says, "Oh, lovely" As a normal people, no one will take what Kim says as a something pleasing or delightful, or having attractive qualities. It is clear that Kim is being ironic, a use of words which is to express the contradictory of literal meaning. None of the dictionary entries will help everyone understands that what Kim means is to express disgust and annoyance. "That's because a word's meaning is one thing, and Kim's meaning - what Kim means by using the word - is something else."

\subsection{Figurative Language}

a. Definition of Figurative Language

BBC (British Broadcasting Corporation) (2014) defines that "figurative language as language which uses figures of speech." It means when someone says something but he or she does not really mean it literally, he or she is using a figure of speech. It is also what Raymond W. Gibss (2015) states in his online encyclopedia that "figurative language allows speakers/writers to communicate meanings that differ in various ways from what they literally say." However, "figures of speech are not devices 
to state what is demonstrably untrue. Indeed they often state truths that more literal language cannot communicate, they call attention to such truths; they lend them emphasis." (X.J. Kennedy, 1966:487) So, it can be concluded that figures of speech which departures from logical usage are not to be taken literally (Sylvan Barnet,et.al., 1963:332).

James R. Kreuzer, and Lee Cogan (1960:304) state that Most people might have thought that figurative language is the province of poetry rather than prose, but it actually does have its place in prose. Using figures of speech appropriately both in writing and speaking can communicate a thought effectively. There are a number of reasons why speaking or writing through figurative language can be such a smart choice. For instance, when comparison is the basis of the figure, the writer or speaker has the opportunity of achieving compression through kinds of figurative language which are simile and metaphor. Moreover, figurative language can surprise or even shock the readers or hearers that how rich the meaning of a group of words can have. The last but not least, a good figurative language as the creative imagination of the writers or speakers can give the pleasure to the readers just like what the painters do with their paintings or the sculptor does through his a piece of sculptor.

Different linguist might have different perception in dividing the kinds of figurative language. Kreuzer and Cogan says that simile and metaphor are the most frequently used figures of speech. Other frequently used figures of speech according to them are metonymy, synecdoche, personification, hyperbole, and litotes. Meanwhile, Barnet, Berman, and Burton in their book mention the figurative languages are simile, metaphor, synecdoche, metonymy, and apostrophe. Then, Kennedy divided figurative language into metaphor, simile, personification, apostrophe, overstatement (hyperbole), understatement, metonymy, synecdoche, transferred epithet, paradox, and pun. Based on those three different linguists, the researcher uses the kinds of figurative language by Kennedy for he explains more completely than two other do. They are discussed in the following section.

\section{b. Kinds of Figurative Language}

a). Metaphor

J. Lawrence, cited in Gillian Lazar (1996:43) The word metaphor derives from the Greek 'meta' which expresses change, and 'pherein' which has meaning 'to carry'. In other words, metaphor involves a 'carrying across' of meaning from one object to another. Metaphor can also be said as a statement that one thing is something else which is in literal sense, it is not. This saying "time is money" which is very common in the daily conversation is a result of metaphor. Most people might lack of notice that metaphor, or even any other kinds of figurative language, has become a part of daily spoken language. Lakoff and Johnson (1980:454) even say 
that metaphor is pervasive in everyday life, not just language, but in thought and action.

Patrick Griffiths (2006:86) states that Metaphor belongs to both an explicit and implicit comparison. When a figure of speech contains words such as like or as, it makes a comparison explicitly. Omitting the connectives develops a comparison in metaphor to be a hidden comparison or an implicit one. Recognizing metaphor just by paying attention to the presence or absence of a connective is no longer such an accurate way, even though it is the most frequently done. One thing should be kept in mind is metaphor implies a comparison between two unlike things which have one or more points in common by speaking of one thing in terms of another or by identifying one thing with another (James R. Kreuzer, and Lee Cogan, 1960:304).

An example of metaphor expression is taken from a novel by Frank McCourt entitled Angela's Ashes (1996:132) : A Memoir, "Your mind is your house and if you fill it with rubbish from the cinemas it will not rot in your head. You might be poor, your shoes might be broken, but your mind is a palace." Through those sentences, McCourt first compares mind with house which has been known that mind and house are two different things, but in this context, they have one thing in common. Both mind and house are a place used to be filled with "rubbish from cinemas." Then, he compares mind with palace. They are identified as two unlike things, but similar as a place which has everything precise inside of them. McCourt might be poor, but he could think of his mind as a palace which surely has riches beyond belief to him.

According to the example above, briefly, it can be said that metaphor is an intensely useful literary device. Using metaphor help authors present unfamiliar ideas or situations in ways that the reader is able to comprehend by comparing unknown things to known things. Metaphor can also help readers create the world the authors created in their literature seem more familiar. The literary works then can be appreciated by the readers in new way. That is why there are many examples of metaphor can be found in literature.

b). Simile

Just like metaphor, simile is also the most frequently used figures of speech according to Kreuzer and Cogan (1960), they state a simile is an expression of a comparison between two unlike things which have one or more points in common. Items from different classes explicitly compared by a connective such as "like," "as," or "than," or by a verb such as "appears," or "seem" can be found in a simile. In addition, Kennedy also states the 
same that a simile is a comparison of two things, indicated by some connective, usually like, as, than, or verb such as resembles. It can be concluded that simile is a figure of speech that makes a comparison, showing similarities between two different things with the help of the connectors. Those connectives themselves can also be as a differentiator between metaphor and simile.

Just because there is found a connective in a comparison does not mean it is a simile. "My sister's new shoes are like mine" is not a simile although it has a connective. Correctly, there are two things being compared, but the things compared have to be dissimilar in kind for a simile to exist, while they are in that sentence compare the same. In other words, if the objects compared are from the same class such as in "Hong Kong is like Shanghai" simile is absent.

An example of simile is given by Margaret Atwood (1985:95) in her novel entitled The Handmaid's Tale, "I wait, washed, brushed, fed, like a prize pig." The sentence might be as a simple simile but it is not at all when looked at more closely. Atwood compares herself with very different thing, pig, but they have one thing in common, that is she is treated no differently than - and no better than - an animal. Also, the word connective like gives a help to easily determine that it is simile.

c). Personification

Kennedy (1966:495) defines that "personification is a figure of speech in which a thing, an animal, or an abstract term (truth, nature) is made human. Or in other words, when the attributions of human feelings or characteristics are given to abstractions or to inanimate objects, it can be called as a personification (Sylvan Barnet, 1963:335). In which human qualities and characteristics are attributed to inanimate objects, as in "this old car eats up gas by the gallon" is a simple definition of personification. The verb eat as in the example above is used by all human living only. Whenever all human living's qualities are given to an inanimate object, it is called personification.

Personification is used to help the authors describe a condition or something more vividly. Through personification, the reader can more easily grasp what the authors want to tell due to the fact that personification expresses the way human perspective works and can figure it out more clearly. One more thing, using personification correctly can make all the written literary works, especially novel, more interesting. It also can help beautify the written works through its out-of-usual-form of description, and 
no doubted, readers never ever be bored enjoying all kinds of written literary works for they seem see the stories more alive. It can be concluded that personification is such a helpful and useful device for an author.

For instance, when someone says, "The moon smiles at you" he is giving the moon ability to smile which is human quality. As it has been known, that how can the moon smile? Therefore, it can be said that the person has personified the moon in the given example. Through that personification, the readers might be told that no one is truly alone, even the moon can smile at you. The personification can show the readers how rich the meaning of a word actually has more than the readers could have ever imagined.

d). Apostrophe

Sylvan Barnet, et. All., (1963:335) state that Another kind of figure of speech is called apostrophe, which has been defined as "an address to a person or thing not literally listening." Kennedy (1966:496) defines apostrophe as "a way of addressing someone or something invisible or not ordinarily spoke to." Apostrophe does not give life to the inanimate objects, which is done by personification. Meanwhile, Kennedy says apostrophe is a way of giving body to the intangible, a way of speaking to it person to person, as in the words of a moving American spiritual: "Death, ain't you got no shame?" Furthermore, apostrophe in literature is "an arrangement of words addressing a nonexistent person or an abstract idea in such a way as if it were present and capable of understanding feelings."

As a simple identification of defining apostrophe in literature, it is sometimes represented by exclamation " $O$ " The use of "O" itself may be put in front of the object and is to announce lofty and serious tone as an "O moon!" For instance, one of William Shakespeare plays, Macbeth, shows an apostrophe. It is written "Is this a dagger which I see before me, the handle toward my hand? Come, let me clutch thee! I have thee not, and yet I see thee still." The apostrophe in the example above is Macbeth has a strange vision of dagger and talks to it if it were another person. Another example comes from James Joyce's novel entitled $A$ Portrait of the Artist as a Young Man writes "Welcome $O$ life! I go to encounter for the millionth time the reality of experience and to forge in the smithy of my soul uncreated conscience of my race." Being able to talk to life is possible only in literature and only apostrophe does.

e). Overstatement (Hyperbole) 
Kennedy states that emphasizing a point with a statement containing exaggeration, what is spoken not literal but truth use a figure of speech is called overstatement (or hyperbole). Gibbs also states similarly that "hyperbole is where a speaker exaggerates the reality of some situation." In addition, hyperbole is derived from a Greek word which means "overcasting." It belongs to a figure of speech involving an exaggeration of ideas for the sake of emphasis. More simply, hyperbole is an exaggeration expression which is to emphasis an idea.

In fact, hyperbole is used not only in literature but in the daily life as well. However, hyperbole has its right place in literature. It has very serious implications. When a literary man uses hyperbole, he makes a common human feeling remarkable and intense to such an extent that they do not remain ordinary. Besides that, hyperbole can bring an amusing effect to the readers. That is why, hyperbole can last longer ordinarily.

An example of hyperbole found in day-to-day conversation as in when someone who meets a friend after a long time then says, "Ages have passed since I last saw you." He may not have met him for three or four hours or a day, but the word "ages" has exaggerated his statement in order to add emphasis to his wait. Another example found in literary work is W.H. Auden's poem As I Walk One Evening. It is written

"I'll love you dear, l'll love you

Till China and Africa meet,

And the river jumps over the mountain

And the salmon sing in the street,

I'll love you till the ocean

Is folded and hung up to dry"

The use of hyperbole can clearly be seen in the above lines. When will China and Africa be possibly met? How could the river jump over the mountain? Can salmon sing, even in the street? Is there something or someone in this world can fold the ocean and hang it up to be dried? The exaggerations have raised those questions up which none of them are possible in real life.

\section{f). Understatement (Litotes)}

Kennedy says the opposite of overstatement is understatement which implies more than is said. On the other hand, a figure of speech which employs an understatement is called litotes. Kreuzer and Cogan defines litotes as a figure of speech which achieves understatement through the 
negation of the opposite of what is meant." Litotes itself is derived from a Greek word which means "simple". It is a figure of speech which employs an understatement by using double negatives or, in other words, positive statement is expressed by negating its positive expressions. For instance, in which someone is avoiding saying "I am old", he says "I am not as young as I used to be. The example shows a positive statement by negating its positive expression. Therefore, according to those definitions, the researcher calls this kind of figure of speech as litotes.

Gibbs simply defines litotes as "where a speaker says less that is actually the case." In addition to what Gibbs says, litotes adds emphasis to the ideas rather than decrease their importance. It means that using litotes is to more strengthen the ideas. This is due to the fact that litotes produces ironical effect by the understatement. It is one of what makes litotes interesting to use.

Without realizing the term and its usage, litotes has been used commonly in everyday life, though. Through many examples found in daily conversations, the statement could not be disagreed. For example, while saying "Your bedroom is clean," people prefers to say "Your bedroom is not unclean." Or, "She is not the most beautiful girl I have ever met" to tell that "She is ugly." There are many more examples can either be found or created.

g). Metonymy

Patrick Griffiths states "traditional accounts of metonymy define it in terms of a person or object being referred to using as the vehicle a word whose literal denotations is somehow pertinently related." Kennedy defines it as "the name of a thing is substituted for that of another closely associated with it." Or it can also be stated that in metonymy, a type of metaphor, something is named by replacing with which it closely relates to. The point of those three definitions of metonymy is the words must have a closed meaning. It can be concluded that metonymy is a figure of speech that replaces the name of a thing with the name of something else which has a closely associated in meaning.

Like all kinds of figures of speech mentioned before, metonymy is also used in everyday life as well. People are likely uncommon with the term of metonymy, they use them as well, however. For a better understanding, let's have a look at this given example. The sentence "Let me give you a hand" is in fact used and heard in day-to-day life. The sentence belongs to a metonymical term. "Hand" in the example has been 
replaced for the word "help". Thus, it can be understood that "hand" and "help" has a related meaning.

Another example of metonymy that has been successfully used by the literary men in their literary works is Shakespeare's Julies Caesar Act I. It is written "Friends, Romans, countrymen, lend me your ears." The one who says it is Mark Anthony. He wants the people who present pay attention to him and listen to what he says about. He has used his sentence metonymically as the word "ears" replaces the concept of attention. The meaning of the two words relates to each other.

It can be seen that metonymy can give a profound meaning to a common idea or object. The texts consisting of metonymy bring deeper or hidden meanings and surely it can draw reader's attention. Furthermore, its function as literary device which is to employ adding a poetic color to literary works is very obvious. It is in order to make them come to life. Through metonymy, it is an effective way to insert a "life" factor to the literary works that can make them more real. As rich a meaning of words combined metonymically has as creative authors it could be.

h). Synecdoche

According to Kennedy, synecdoche is a kind of metonymy. Synecdoche is "the use of a part of a thing to stand for the whole of it or vice versa." While Barnet, Berman, and Burto state that synecdoche is the second type of metaphor. They define it as the whole which is replaced by the part, or the part by the whole. Another definition agreeing with what Kennedy says comes from Kreuzer and Cogan. They state that synecdoche is "a special form of metonymy by which a part is put for the whole or the general for the special." Since there are two definitions which shares the same saying that synecdoche is a part of metonymy, the researcher follows that definition. Nevertheless, the core of what synecdoche is really about has been answered by all the experts due they define it similarly.

As a part of metonymy, synecdoche examples are often misidentified. They both may resemble each other to some situation but they are different. Synecdoche refers to the whole of a thing by the name of any one of its part whereas metonymy, as mentioned above, is the words used to describe another thing which is closely linked to that particular thing. For example, sentence "All fingers are raised up for his thought" belongs to a synecdoche. "All fingers" stands for a whole person, or in other words, it is a part for general. Meanwhile, Kwave or Korean Wave is a term used to refer all things that relates to all about Korea. As in "Korean wave spreads so 
fast," it refers to not only about the Korean celebrity itself but also the culture, the foods, even the country. It can be noted that Korean wave can act as a metonymy for Korea. Therefore, both metonymy and synecdoche clearly are not the same.

For more comprehension, like other kinds of literary devices, synecdoche is also very common to be found in literature. Frank S. Stockton's work entitled "The Lady or the Tiger?" shows the readers an example of synecdoche. He writes "His eyes met hers as she sat there paler and whiter than anyone in the vast ocean of anxious faces about her." The word "face" there refers to people, not just their faces. Moreover, people use synecdoche in casual conversation as well. People often use a part of something to refer a particular object wholly. For instance, when a car is called as "wheels", it means synecdoche is being produced for one of the parts of a car is wheels.

The purpose of using synecdoche is quite similar to metonymy and other figures of speech. It makes the literary works more vivid through adding distinct color to the words. Then, the vividness can also make the works more real and alive. In addition, the use of synecdoche can create brevity to whoever uses it. It can be seen through this example, saying "Soldiers were equipped with steel" is more concise than saying, "Soldiers were equipped with swords, knives, daggers, arrows, and any other kinds of weapons which made of steel. The last but not least, as a literary device, making the works more artful without alleviating the meaning of the words can wonderfully be achieved, the reader's attention can be drawn successfully either.

\section{i). Transferred Epithet}

Besides synecdoche, transferred epithet is, refers to Kennedy's definition, also a kind of metonymy. It is "a device of emphasis in which the poet attributes some characteristic of a thing to another thing closely associated with it." In other words, Shenghuan defines it as "a figure of speech in which the epithet is transferred from an appropriate noun to modify another to which it does not readily belong." Warren shares the same that transferred epithet is "adjective that appears to have been transferred from adverb to prenominal position... ." Epithet itself is "a descriptive literary device that describes a place, a thing or a person in such a way that it helps in making the characteristics of a person, a thing or place more prominent than they actually are." So it can be concluded that a transferred epithet is a figurative language that contains an adjective or adjectival phrase or an adverb which modifies a noun. 
For instance, the phrase "dreamless sleep," dreamless is the epithet. Thus, a transferred epithet which is also known as hypallage meaning literally "echange" is an adjective or adverb which is transferred from noun it logically belongs with, to another which fits it grammatically but illogically. Then, in "dreamless night", dreamless is a transferred epithet since the word "dreamless" is an adjective and modifies the noun "night". It fits grammatically but not logically for the exact meaning of the phrase is "night when someone slept without dreaming" and a night cannot actually dream anyway (Will Martin, 2015: para 2).

Without being aware of using this literary device, transferred epithet has been greatly used either in daily spoken or in literary works. For instance, people often say "I had terrible day." The word "terrible" modifies the noun "day." It fits grammatically but has illogical meaning. It was not the day that was terrible, only the things that happened to him on that day. An example coming from literature is a poetry written by Homer entitled The Odyssey. The verse containing an epithet is "Sailing across the wine-dark sea to men." The phrase wine-dark is an adjective phrase that modifies the noun "sea." The meaning is to describe the color of the sea. It enhances the description of color of the sea.

According to the explanation above, it can be agreed that epithet is very useful and helpful both for the writers and the readers. The writers are able to describe the characters and settings more vividly by giving richer meaning to the text through the use of epithets. Epithet can also help the writers develop suitable images to their works in fewer words. Since the writer can make the description of someone or something broader, the readers can understand the literary works more easily, too. They become more interesting to enjoy for the vibrant and strong images they have.

\section{j). Paradox}

Kennedy says that "paradox occurs in a statement that at first strikes us as self-contradictory but that on reflection makes some sense. While Barnet, Berman, and Burto say that "the element of contrast is so sharp that we feel it is almost an impossibility, a contradiction in terms, a paradox. Paradox has several meanings for philosophers, but we need only be concerned with its meaning of an apparent contradiction," In addition, "the term paradox is derived from the Greek word "paradoxon" that means contrary to expectations, existing belief or perceived opinion. It is a statement that appears to be self-contradictory or silly but may include a latent truth." Simply, it can be said that paradox is a statement which contains a contradictory. 
To be clearer, let's see the following examples of paradox which are found both in everyday life and literature. The statements "Your enemy's friend is your enemy" and "truth is honey which is bitter" are the contradiction ones. The first sentence points out that the words "friend" and "enemy" are at cross. The second one is honey which has been known containing a sweet taste, but be contradicted by saying it is bitter. Then, it makes people more realize that eventually paradox is used oftentimes. Another example is taken from George Orwell's novel entitled Animal Farm. The statement says "All animals are equal, but some are equal than others." It shows a contradictory, thus it belongs to a paradox. However, it needs a deeper examination to get clear that Orwell's actually would like to point out a political truth. That is one of the paradox it is - containing a latent truth. Orwell in his novel wants to criticize the government that claims everyone is equal but it has never treated everyone equally. It is the concept of equality stated in a paradox that is opposite to the common belief of equality.

After figuring out the examples, the functions of paradox can be summarized. Paradox makes the reader to think over an idea in innovative way. If the readers do not get the understanding comprehensively, the sentence will not make any sense. Like many other previous literary devices, the major purpose of paradox is to give pleasure to the readers. That is what makes literary works different with those served in an uncomplicated manner. Readers will more enjoy the works when they have to extract the hidden meaning out of the writing. They will get the real message the writers want to tell about said through paradox.

k). Pun

Kennedy explains that pun is a play on words. It is a figure of speech which is better known to classical rhetoricians as paranomasia. Pun calls up the readers of another word (or other words) of similar or identical sound but very different denotation. In other words, a pun is a play on words that produces humorous effect by using a word that suggests two or more meanings or by exploiting similar sounding words having different meanings. Humorous effects created by puns depend upon the ambiguities words entail. The ambiguities arise mostly in homophones and homonyms. Hereinafter, Kjerkegaard define pun more precisely as "a play on words, sometimes on different senses of the same expression and sometimes on the similar senses or sounds of different words." Thus, it can be simply concluded a pun is a word playing. 
People may not recognize that they have frequently used pun either in their communication with each other or in making jokes and witty remarks. Here the example is, "What is the difference between a conductor and a teacher? The conductor minds the train and a teacher trains the mind." The example above is obviously a play on words and successfully creates a joke and witty remark. It is proved that pun has been used more greatly in daily life.

The following example also shows that literature uses pun extensively. It is taken from William Shakespeare's Romeo and Juliet. It is one of Romeo's dialogues, said "Not I, believe me. You have dancing shoes with nimble soles; I have a soul of led." The two underlined words are the use of pun in the drama. They belong to homophones which exploits similar sound but different meaning. The sentence is intended to say that he will not dance. However, there are many more examples which can be found in literary works using this kind of figure of speech, and need to be given more awareness about their presence.

Besides giving a humorous and witty effect, a pun also can add profound meanings to the texts and shape the way in which text is interpreted by the readers. By playing with the words, the writer can reveal their cleverness and the cleverness of their characters. Moreover, pun can help provide the writers such another way to create their new works with bunch of word choices. The richer words the writers use, the more creative they are. The richer words the writers put on the works, the more impressed the readers will be.

\section{B. METHODOLOGY}

The researcher uses qualitative approach in studying this research. Qualitative research itself is a type of research which is not to quantifying or using statistical methods (Health Research Authority, 2015). Several characteristics of this research are it focuses on words and their meanings and, as it is defined, does not seek to count things statistically. Referring those explanations, it can be concluded that the qualitative approach is the best to apply for conducting this term paper.

The researcher of this term paper surely needs data to be collected, observed, and analyzed. It is called as research data. Therefore, the data in this research is all sentences which consist of kinds of figurative language mentioned in Chapter II. 
The place where data is taken is called as data source. The source of the data for this research is taken from a novel written by Jenny $B$. Jones entitled There You'll Find Me (2011) published by Thomas Nelson (USA).

\section{FINDING AND DISCUSSION}

In this chapter, the researcher discusses the analysis of the types of figurative language in the novel There You'll Find Me. Figurative languages are characterized by the use of bold type in the data. Either the connective words of figurative language or the sentences containing figurative language are marked with underline type. In this explanation, the researcher explains about the story briefly followed by the types. However, the researcher does not explain all figurative language found in this novel. It is taken only some of each type of figurative language randomly since the objective of this research is to find what types of figurative languages the novel used, to know what type of figurative language widely used, and the least one, while all findings are given in the following table in this chapter.

\section{a) Metaphor}

Jenny B. Jones $(2011: 1)$ states that Metaphor is a comparison between two different things which have one or more similarities by speaking of one thing in terms of another or by identifying one thing with another. In metaphor $A$ is $B$ which can be interpreted as one thing is something else even though in literal it is not. An example of metaphor is your presence is the light of my day. The sentence is to compare someone's presence with the light of someone's day. Those things are very different but have one thing in common. Both his presence and the light are very needed in her life. They are the important things of someone's life. Next, the followings are several examples of metaphor found in the novel.

\section{Example}

What if it fell?

What if the breeze took it away?

I counted the seconds until I could reel it back in.

\section{I was that kite.}

The example above is uttered by one of the lead characters named Finley Sinclair. She was thinking back the moment when she was with her brother who passed away two years ago flying their kites. She was wondering what would happen to her kite. Apparently, things that would happen to the kite were what she was worry about that would happen to her, 
too. That was why she compared herself with the kite by saying I was that kite.

b). Simile

Simile is a figure of speech that makes a comparison which shows similarities between two different things with the help of connectors. The presence of the connectors which makes simile is explicitly noticed. The connectors are such as "like", "as", or "than" or by a verb such as "appear", or "seem." In metaphor, A is B while in simile A is like B. For instance, we can never meet just like day and night. This is a simile expression as it shows a comparison between what happens to the two people which is replaced by the subject we and day and night. Although they in literal are different things, as simile, they have similarity. It is known that day and night can never ever be met, they aren't either. Instead of just saying we can never meet, the speaker does emphasize the situation by adding a comparison through simile. Here are several simile expressions found in the novel.

\section{Example}

I slipped into the music room and, with my back pack still in my lap like a shield, I took a seat at a piano old enough to have been carried over on the ark.

The sentence above is uttered by Finley. She wants to describe her back pack by comparing it with a shield. The similarity found among the difference between them is why she didn't directly put her back pack down when getting in the place she headed. She did keep her back pack in her shoulder just like a shield which is always close to its owner. This simile expression helps the readers get a real imagery about the situation in the story. It makes the story more vivid.

\section{c). Personification}

Personification is a figure of speech in which qualities and characteristics of human being are attributed to abstractions or inanimate objects. Personification makes all non-living things do what human living usually does. For instance, "The brightest star above winked at you." The star which is a non-human entity has been personified. It was made to be able to perform what the living things do that is it could wink at somebody. Thus, when inanimate objects attribute human living's qualities, it is when personification applied. Below are a few examples of personification found in the novel. 


\section{Example}

\section{His forceful words hung between us, balancing between his interpretation and mine.}

Finley was having a conversation with Beckett that he wanted her to be his personal assistant. Finley refused his offering as she doubted his motives why on earth an adorable actor like him wanted an ordinary girl like her to be the one who would spend most of her time with him. Thus, his forceful words mean what Beckett said to Finley to ask her to be his personal assistant, helping him practice his dialogue on script. Word or his forceful words which is an abstract thing has been personified to be able to perform as a living thing. It can hang between Finley and Beckett and balance between her interpretation and his.

\section{d). Apostrophe}

Words or utterances which are addresses to a person or thing not literally listening is called apostrophe. Apostrophe is a kind of figure of speech which consists of a way of addressing someone or something invisible or intangible, or not ordinarily spoke to. For instance, when someone would like to express his longing to his beloved girl while could not find a way to tell her straightaway. He probably might say, "O moon, tell her how I miss her much" The man has addressed the moon his speech since the moon itself is the intangible thing. Speaking to the moon is not an ordinary to do and the moon is not an ordinary speaking to. The followings are a few examples of apostrophe found in the novel.

\section{Example}

Lord help me, if my mom finds out, I'm dead. She'll make me come home.

When celebrating the St. Flanagan's day, Finley keeled over. Everybody tried to see her condition. Then, Mr. Plummer, the school principal and also the owner of the school, came to check and help her. He suggested her to call her mother and told what had just happened. She refused the suggestion, and in her heart, she spoke to God who is invisible and intangible. She begged God to help her. Her speaking to God which is not literally listening, according to the theory in chapter two, belongs to apostrophe. 


\section{e). Overstatement (Hyperbole)}

Overstatement or hyperbole is a figure of speech containing exaggeration expression. It is to emphasis the idea the speaker or writer would like to pour out. Moreover, using hyperbole can make the expression remarkable to the hearer or the reader since it remains unordinary. For instance, he faced thousands of problems lately. This expression has been exaggerated. It did not say he faced a lot of problems, he faced thousands, instead. Then the exaggerated expression has successfully emphasized the idea and has been remain remarkable. The followings are several examples of hyperbole found the novel.

\section{Example}

His chest rose as he took a deep breath "I can't complain about what l've had. I could quit work today and still be set for life. I have a garage full of cars in all five of my house. Friends all over the world. A first-class seat on any plane going anywhere I want."

The above sentences are uttered by Beckett Rush. He is a famous actor, and of course, is wealthy, also. He has exaggerated his statements about how many things he could easily get through his popularity and wealth. Instead of saying "I am a rich man." He exaggerated it with what he said above that even he quit work today, he still could fulfill his life. He did not need to be worry about everything included money as he still can survive in this life without even working. Then, people usually mention the exact number of cars they have while Beckett did different. He exaggerated about how many cars he had. His five houses had at least five garages, it was very possible it had more, and all of the garages were full of cars. It is clearly described that he had lots of them. As a famous actor who was blessed with a handsome face, many people especially girls adored him so is such a fair thing. Again, he did not say it ordinarily, instead he had friends all over the world. It means that his popularity reached every hemisphere this earth has. Every single one in this universe knows him. What an exaggeration! And, since he had more-than-enough money, he surely could go anywhere he wanted, sat in the first class on any plane.

\section{f). Understatement (Litotes)}

Understatement is the opposite of overstatement. A figure of speech which employs an understatement is called litotes. Litotes is expressed by using double negatives to convey its positive statement, or in 
other words, positive statement is said by negating its positive expression. For instance, people like saying "I'm not that old." to avoid saying "I'm still young." It clearly explains that not old is the negative form of the positive expression young. A few examples of litotes found in the novel are the followings.

\section{Example}

\section{Dysfunction was apparently a family epidemic. I had it. I didn't know anyone who didn't.}

After being abandoned by her beloved brother, Will, forever, Finley run her life in painfulness and anger. She was even disappointed not only to God which seemed silent seeing that tragic event but also her own family which seemed taking for granted the tragic death of Will. The family's atmosphere was no longer the same. The function of a family, which has to keep stronger and strengthen each other, did not well run. The emptiness had taken the function away. Besides, she knew one thing, what happened to her family happened to others', too. That was why she said dysfunction was a family epidemic. Also, according to the theory, litotes can be found by negating its positive expression to get its positive statement. "I didn't know anyone who didn't" consists of negative expressions which the positive meaning is I know that anyone did it is clearly an overstatement or litotes expression.

\section{g). Metonymy}

Metonymy is a kind of figure of speech in which the name of a thing is replaced with the name of something else which is closed in meaning. The way metonymy works is it changes the word without changing the meaning the word has by providing new referents which have connections between the concepts. The reason using metonymy is simply to address something in a more poetic and unique way. That's what figurative language is for. A popular phrase which actually is a metonymy expression is the White House. The phrase is oftentimes used as a replacement of the people who work in it. For example, the White House is concerned about global crisis. It can be understood that is not the White House, which is only a building, that concerned about global crisis but the people who work in it did. Therefore, the sentence the people who work in the White House has been replaced with the White House which the meaning between them is associated. Let's have a look at some metonymy expression below found in the novel. 


\section{Example}

\section{So many things seemed out of control in my world.}

Finley had a lot of things which every single one of them needed to think about. Unfortunately, she was not as great as she thought she was. Those things seemed out of control in her world. The word world in that context has a closed meaning with life. It can be concluded that the word life has been replaced with world. Life keeps all things that happened, so does world. It takes all things in. Thus, so many things seemed out of control in Finley's world which is meant Finley's life.

\section{h). Synecdoche}

Synecdoche is a figure of speech that consists of the use of a thing to stand for the whole of it or vice versa. In other words, a part of something is put for the whole or the general for the special. It refers to the whole of a thing by the name of any one of its part. For instance, when a man is asking her fiancée to marry him, he can express it by a saying ask for her hand. It is easily understood that the man is not asking the woman's hand to marry him, instead she herself. It can be concluded that hand which is a part of the body belongs to a synecdoche expression as it stands for the whole woman. The other several examples of synecdoche which were found in the novel are as follows.

\section{Example}

I continued to read the article, but it provided no new information, and soon the words swam and blurred until I finally had to close my eyes and rest for just a bit in the dimmed lights of the plane.

Finley was in her way to Ireland. She spent her leisure time during the flight by reading an all set newspaper. She got sleepy, then. Sleep is the one she needed. She expressed it by saying "... and rest for just a bit in the dimmed lights of the plane." Also, she had previously said that she had to close her eyes as a metonymical expression which means she had to sleep. The phrase the dimmed lights of the plane belongs to a synecdoche expression. She could not rest in the dimmed lights of the plane, but she could do that in the planes itself. Therefore, the dimmed lights of the plane are a part of a plane which stands for the plane wholly. 


\section{i). Transferred Epithet}

Transferred epithet is a figurative language containing an adjective or adjectival phrase or an adverb which is used to modify a noun. The adjective or the adverb modifies the noun it logically belongs with, to another which fits grammatically but illogically. This illogical statement the transferred epithet makes can precisely describe a thing or a person more prominent than they actually are, instead. For instance, to express their unforgettable moment people like to say "Last night is my happiest night." The phrase "happiest moment" is a transferred epithet example. The superlative-degree adjective happiest does modify the noun night with which it logically belongs. They fit grammatically but illogically. The night cannot feel the happiness, people can. Thus, it is not the night which is happy, the person is. That is what fit grammatically but illogically meant. Giving character to the noun night make it more prominent than it actually is. A few transferred epithets found in the novel are as follow.

\section{Example}

\section{"Are you okay?" He glared at a few standing too close. "Step back. Give her some breathing room."}

Finley keeled over. Beckett got shocked and helped her immediately. He said to the people who crowded around her to step back and give her some breathing room. What Beckett meant is to give Finley enough air to breathe. The phrase "breathing room" is one of the transferred epithets found in the novel. The adjective breathing has modifies the noun room. They fit grammatically but illogically due to the fact that it is not the room which is breathing, the living things are. It is proved that transferred epithet has made the phrase "breathing room" more prominent.

\section{j). Paradox}

Paradox is a figurative language that occurs when the statement contains a contradictory. The statement can be as a self-contradictory but may include a latent truth. For instance, when someone says "I am nobody," he says a paradox. "I am nobody" contains a self-contradictory. "I am" means somebody but saying "nobody" has created a contradictory. Below are several paradoxes found in the novel.

\section{Example}

She called her eyes. "Does it ... does it look like l'm all right?" 


\section{"Let me call the nurse"}

"No" Her whisper sounded loud in the still room. "Just help me up. I'm. . . I'm too weak."

Finley was visiting Mrs. Sweeney. After opening the door, she found her lay on the floor in a heap, eyes wide, shaking. She got to help her as possibly as she could. She asked whether her condition was all right, and she whispered she was not. As it is known that when someone is whispering, she is speaking very quietly, using the breath but not the voice. So, how come a whispering can sound loud? It can be concluded that "Her whisper sounded loud in the still room" contains contradictory. Thus, it belongs to paradox.

k). Pun

Pun is a figure of speech in which words are playing, or in other words it is a word playing. It uses the words which have similar sound but different denotation and meaning. Frequently, pun raises ambiguities when applied. The ambiguities are mostly come from the use of homophone and homonym. However, the ambiguities the pun creates can add humorous effect to the writing. The followings are the example of pun found in the novel.

\section{Example 1}

"Have you guys ever seen this?"... "This cross?"

Orla took a look first. "They're all over the country."

"You have to find that exact one?" Erin asked.

I quickly explained. "I can't finish my song without it. And if I don't finish my song, l'll mess up my audition with the New

York Conservatory. Again"

"Cross yourselves." Orla glared over my shoulder. "Here comes Beatrice."

As it is said that pun is a play on words which sometimes on different senses of the same expression or the same senses of different expression. The word cross had been used with different senses. The one is the cross as a thing which Finley very needed to find and the other one is Orla's expression of her surprised when glaring at Beatrice's coming by saying "Cross yourselves." Thus, the word cross in this part of the novel had been used in the different senses, then it belongs to pun. 
Table 4.2 The Percentage Use of Figurative Language

\begin{tabular}{|c|l|c|c|}
\hline No. & \multicolumn{1}{|c|}{ Figurative Language } & Total & Percentage \\
\hline 1 & Metaphor & 35 & $7.3 \%$ \\
\hline 2 & Simile & 70 & $14.6 \%$ \\
\hline 3 & Personification & 81 & $16.9 \%$ \\
\hline 4 & Apostrophe & 15 & $3.1 \%$ \\
\hline 5 & Overstatement (Hyperbole) & 23 & $33.8 \%$ \\
\hline 6 & Understatement (Litotes) & 20 & $4.8 \%$ \\
\hline 7 & Metonymy & 18 & $3.2 \%$ \\
\hline 8 & Synecdoche & 37 & $7.8 \%$ \\
\hline 9 & Transferred Epithet & 3 & $3.1 \%$ \\
\hline 10 & Paradox & 479 & $0.6 \%$ \\
\hline 11 & Pun $\quad$ Total & $100 \%$ \\
\hline
\end{tabular}

Based on the table of list of figurative language above and the percentage of each of them, the researcher would like to answer the limitation and formulation problem in chapter one of this term paper. There are three points, and the first point is what kinds of figurative languages used in the novel, the second is thev figurative language used most in this novel, and last the figurative language used least in this novel.

\section{The figurative languages are used in this novel}

There are eleven figurative languages that frequently used in any kinds of literary works. They are metaphor, simile, personification, apostrophe, overstatement (hyperbole), understatement, metonymy, synecdoche, transferred epithet, paradox, and pun. Those kinds are based on the theories that the researcher mentioned in chapter two. After doing the analysis, the researcher found that the novel used all of those eleven figurative languages: metaphor, simile, personification, apostrophe, overstatement (hyperbole), understatement, metonymy, synecdoche, transferred epithet, paradox, and pun. 


\section{The figurative language used most in this novel}

The second one is about what figurative language widely used in the novel. It can be seen from the table of percentage above, it is overstatement or hyperbole with the total use is 162 or $33.8 \%$. It can be concluded that the author of the novel likes to exaggerate her sentences to describe the story more vivid and more amusing. In addition, it also can be categorized that hyperbole belongs to easiest figurative language to use as it has been used most widely among others.

\section{The figurative language used least in this novel}

The last is what figurative language used least in the novel. The percentage shows it is pun with only three times used throughout the novel and its use is not even up to one percent. Pun is play on words. The author of the novel may prefer, besides using exaggeration, personify the inanimate objects, or compare two different things which have similarities and the use of a connector, to play on words. Therefore, she used pun very minimally.

\section{CONCLUSION}

The study aims to find out what kinds of figurative language used in the novel, what figurative language most widely used, and the least one. All sentences which consist of figurative language are the data analysis of this research. The data source was taken from a novel entitled There you'll Find Me by Jenny B. Jones Published in Thomas Nelson (USA) in 2011. After analyzing and listing all the findings into a table given in the chapter four, the researcher concludes as follows.

The total figurative language the researcher found in the novel is 479 . They contain all of kinds of figurative language mentioned in the chapter two. The figurative languages are metaphor, simile, personification, apostrophe, overstatement (hyperbole), understatement, metonymy, synecdoche, transferred epithet, paradox, and pun. According to the percentage table, the following sequence of figurative language shows that overstatement (hyperbole) sits in first rank with total use of 162 out of 479 or $33.8 \%$, the second position is personification with total use of 81 out of 479 or $16.9 \%$, the third is simile with the total use of 70 out of 479 or $14.6 \%$, next is transferred epithet with the total use of 37 out of 479 or $7.7 \%$, metaphor with the total use of 35 out of 479 or $7.3 \%$, metonymy with the total use of 20 out of 479 or $4.2 \%$, synecdoche found 18 out of 479 or $3.8 \%$, apostrophe and paradox with the same total use of 15 out of 479 or $3.1 \%$, and pun with the total use of 3 out of 479 or $0.6 \%$. Therefore, the figurative language used most widely is hyperbole with the total use 162 or $33.8 \%$ and the east is pun found only 3 or $0.6 \%$ 


\section{BIBLIOGRAPHY}

Atwood, M. (1985). The Handmaid's Tale. Toronto: McClelland and Stewart.

AZlyrics Editors. (2000). AZLyrics Corporation. Dipetik August 19, 2015, dari

AZLyrics Web Site:

http://www.azlyrics.com/lyrics/shakira/cantremembertoforgetyou.html

George Lakoff, a. M. (1980). Conceptual Metaphor in Everyday Language. The Journal of Philosophy, 77, 454.

Griffths, P. (2006). An Introduction to English Semantics and Pragmatics.

Edinburgh: Edinburgh University Press Ltd.

Harvey, R. (2011, November 4). Literature as an Art Form. Dipetik July 7, 2014, dari The Journal Pulp: http://journalpulp.com/2011/11/04/literature-as-an-artform/

James R. Hurford, B. H. (2007). Semantics a Course Book. Cambridge: Cambridge University Press.

James R. Kreuzer, a. L. (1960). Studies in Prose Writing. New York: Holt, Rineheart and Winston, Inc.

Kearns, K. (2011). Semantics. Basingstoke: Palgrave Macmillan.

Kennedy, X. (1966). Literataure an Introduction to Fiction, Poetry, and Drama. Boston: Little, Brown Company.

Kjekegaard, S. (2011). Seven Days without a Pun Makes One Weak: Two Functions of Wordplay in Literature and Literary Theory. The Journal of Literature, Language and Linguistics, 3, 1.

Lazar, G. (1996). Using Figurative Language to Expand Students' Vocabulary. ELT Journal, 50, 43.

Liberman, M. (2011, October 19). About Us: Univerity of Pennsy/vania. Dipetik August 7, 2015, dari The Trustees of Univerity of Pennsylvania: http://www.ling.upenn.edu/courses/Fall_2011/ling001/schedule.html 
McCourt, F. (1996). Angela'sAshes: A Memoir. New York: Scribner.

Raymond Gibbs, a. H. (1999). About Us: MITECS. Dipetik August 10, 2015, dari MITECS Web Site: http://ai.ato.ms/MITECS/Entry/gibbs

Shenghuan, X. U. (2011). Why Is Transferred Epithet Possible? Foreign Language Teaching ana Research 3, 3, 1.

Sylvan Barnet, M. B. (1963). An Introduction to Literature Fiction, Poetry, Drama. Boston: Little, Brown and Company. 